\title{
VARIATION OF WING SHAPE, SEXUAL DIMORPHISM AND DIRECTIONAL ASYMMETRY IN NATURE POPULATION OF THE POECILOBOTHRUS REGALIS (MEIGEN, 1824) (DIPTERA, DOLICHOPODIDAE)
}

\section{A. Chursina}

Military Training and Research Center of Air Force "Air Force Academy Professor N. E. Zhukovsky and Yu. A. Gagarin", 54A Staryh Bolshevikov, Voronezh, 394064, Russia

E-mail: chursina.1988@list.ru

\section{ИЗМЕНЧИВОСТЬ ФОРМЫ, ПОЛОВОГО ДИМОРФИЗМА И НАПРАВЛЕННОЙ АСИММЕТРИИ КРЫЛА В ЛОКАЛЬНОЙ ПОПУЛЯЦИИ РОЕCILOВОTHRUS REGALIS (MEIGEN, 1824) (DIPTERA, DOLICHOPODIDAE)}

\author{
М. А. Чурсина \\ Военный учебно-научный центр военно-воздушных сил «Военно-воздушная академия \\ имени профессора Н. Е. Жуковского и Ю. А. Гагарина», \\ Россия, 394064, г. Воронеж, ул. Старых Большевиков, 54А \\ E-mail: chursina.1988@list.ru
}

Abstract. Background. As taxonomic character of wing venation in dolichopodid flies is often used in taxonomic studies, more detailed observation including variation in shape and pattern of sexual dimorphism between different generations and between sides of individuals has the potential to shed light on evolutionary trends in the family. Materials and methods. A geometric morphometric analysis was conducted to examine the patterns of wing shape variation in the individual population of Poecilobothrus regalis (Meigen, 1824). ANOVA was used to estimate significance of differences among generations, sexes and sides. CVA was performed to allocate these differences. Degree of asymmetry was computed as difference between sizes of left and right wings. Assessment of differences between values of asymmetry in the groups was taken using t-test. Results. An analysis of the data using the Procrustes method found significant intergenerational differences in wing size and shape, and it was shown that the intergenerational shape variation was partly explained by the allometry. Statistic comparison of the amount and pattern of sexual shape dimorphism among three generations reveals no significant differences. In three cases, significant directional asymmetry was found. Conclusion. A comparison of the intergenerational and intra-generational pattern of shape variation and variation, attributed to directional asymmetry, showed their considerable correspondence. There was no significant evidence that level of fluctuating asymmetry may be a measure of the ability of individuals to cope with environmental conditions.

Keywords: directional asymmetry, Dolichopodidae, geometric morphometric, Poecilobothrus regalis, sexual dimorphism, wing shape.

For citation: Chursina M.A. Variation of wing shape, sexual dimorphism and directional asymmetry in nature population of the Poecilobothrus regalis (Meigen, 1824) (Diptera, Dolichopodidae). Russian Journal of Ecosystem Ecology. 2019;4(2). Available from: https://doi.org/10.21685/2500-0578-2019-2-4

Аннотация. Актуальность и цели. Поскольку признаки формы крыла долихоподид часто используются в таксономических исследованиях, более подробное изучение их изменчивости, в том числе между формой и типом полового диморфизма, между выборками одной популяции разных лет и между сторонами одной особи, может пролить свет на понимание эволюционных тенденций в семействе. Материалы и методы. Для изучения закономерностей изменения формы крыла в отдельной популяции Poecilobothrus regalis (Meigen, 1824) был проведен геометрический морфометрический анализ. Аля оценки значимости различий формы между выборками разных лет, полами и сторонами использовался ANOVA. CVA использовался для оценки различий между группами. Степень асимметрии рассчитывалась как разность между размерами левого и правого крыльев. Оценка различий между значениями асимметрии в выборках различных лет проводилась с помощью t-теста. Результаты. Были обнаружены значительные различия в размерах и форме крыла между выборками разных лет, и показано, что вариация формы между выборками частично объясняется аллометрией. Статистическое сравнение полового диморфизма не выявило существенных различий между выборками разных лет. В трех случаях была выявлена значительная направленная асимметрия. Выводы. Сравнение вариаций формы, связанных с изменчивостью внутри и между выборками, показало их значительное сход- 
ство. Не было получено никаких существенных доказательств того, что уровень флуктуирующей асимметрии может быть мерой способности особи справляться с условиями окружающей среды.

Ключевые слова: направленная асимметрия, Dolichopodidae, геометрическая морфометрия, Poecilobothrus regalis, половой диморфизм, форма крыла.

\section{Introduction}

Geometric morphometric analysis of wing shape represents a forward-looking approach to addressing taxonomic concerns. An increasing number of studies in this area is focused primarily on discriminating between morphologically similar species [1-3]. The studies at higher systematic levels allow us to describe evolutionary transformations within characters system [4] and to find phylogenetic signal in wing shape $[5,6]$. High heritability of wing shape was shown in laboratory studies, while wing size is strongly affected by environmental variation $[7,8]$ and probably depends on selection pressure acting in population [9].

The second category of research, based on geometric morphometric analysis, is to quantify fluctuating asymmetry. Because fluctuating asymmetry is a small, random, nondirectional deviation between sides of an organism, resulting from minor developmental accidents and with no genetic basis $[10,11]$, dealing with fluctuating asymmetry requires a high degree of precision. Such degree of precision can be achieved by using geometric morphometric approach.

According to one of the existing hypotheses, fluctuating asymmetry (FA) is claimed both as a measure of developmental stability of population [12], and measure of the ability of individual to cope with environmental conditions during ontogeny. However, the results of studies of FA are contrasting. For example, it was shown that long-tailed males of Hirundo rustica more frequently had symmetrical tails. A number of studies did not indicate relationships between the level of FA and fitness [13-15], while some studies confirm the negative [16] or positive FA association with mating success [17]. Whitlock [18], Breuker, Brakefiel [19], Trotta et al. [20] demonstrated that the level of fluctuating asymmetry is species specific, and it varies according to evolutionary history of separate population and has a low repeatability.

The wing characters are widely used in investigating systematics and phylogeny of the family Dolichopodidae [21, 22]. Morphometric traits were compared with molecular data [23] and results on the use of the test for the presence of a phylogenetic signal in morphometric data were positive, although in some cases distantly related species were closer in shape space than closely related species. In addition, wings in Dolichopodidae are used both for locomotion and courtship behavior [24, 25], because of this, sexual dimorphism exhibits significantly changes on wing shape [26]. Therefore, the diversity of wings shape has been produced by both sexual and natural selection.

However, there are few in-depth studies of changes in the wing shape or sexual shape dimorphism among generations [27] and no research demonstrated that the kind of sexual shape dimorphism could be used as a species-diagnostic character. One individual natural population can provide a model for studying of intraspecific variability and the limits of natural variability. In addition, there is a need for more precise studies of the wing asymmetry pattern. Geometric morphometrics approach allows us to depict a very subtle variation in the wing shape and size. Therefore, the main purpose of this study is to consider the shape variation in several generations of the local population of Poecilobothrus regalis (Meigen, 1824) using geometric morphometric approach. In this paper, we are trying to answer the following questions:

1. Is there a significant difference in the wing shape and size and in the pattern of sexual dimorphism among generations of the population?

2. What kinds of asymmetry characterize the population and do they show high heritability in nature? Does the amount of FA change among generations?

Poecilobothrus regalis is widespread in southern Europe, distinguished by the following set of characters: hind femur with anterior preapical seta, hind basitarsus with 2-4 strong dorsal seta and notopleuron with distinct purple spot. This species is an attractive insect for study because it has an interesting example of sexual dimorphism in the wing color and venation [28]. Males are characterized by the dark apical spot on wings, while female's wings are completely hyaline.

\section{Materials and methods}

Poecilobothrus regalis were collected as adult from the same sites on the bank of the Ziigraevsky Pond (Voronezh region, Kantemirovsky district, village Mitrofanovka, latitude $49^{\circ} 58.2498^{\prime}$ North and longitude $39^{\circ} 41.6334^{\prime}$ East) in July of 2015, 2017 and 2018. Table 1 gives the number of specimens for each year. A total 634 wings (376 males and 258 females) were analyzed. 
Number of specimens of Poecilobothrus regalis used in the study

\begin{tabular}{|c|c|}
\hline Year & Number of specimens (wings) \\
\hline 2015 & 134 ふึ, 76 오오 \\
\hline 2017 & 58 ठิग, 126 우우 \\
\hline 2018 & $184 \hat{o}^{\lambda} \hat{D}^{\lambda}, 56$ 우우 \\
\hline
\end{tabular}

Geometric morphometrics was used to explore the wing size and shape variation. Both left and right wings of each fly were dissected and slidemounted. Wings were photographed using Levenhuk C NG microscope camera and saved. Wings were landmarked with the software TpsDig-2.32 [29]. Eight landmarks (LM) of "type I" [30] were placed at vein terminations and intersections (Fig. 1). In order to quantify measurement errors all wings were digitized twice.

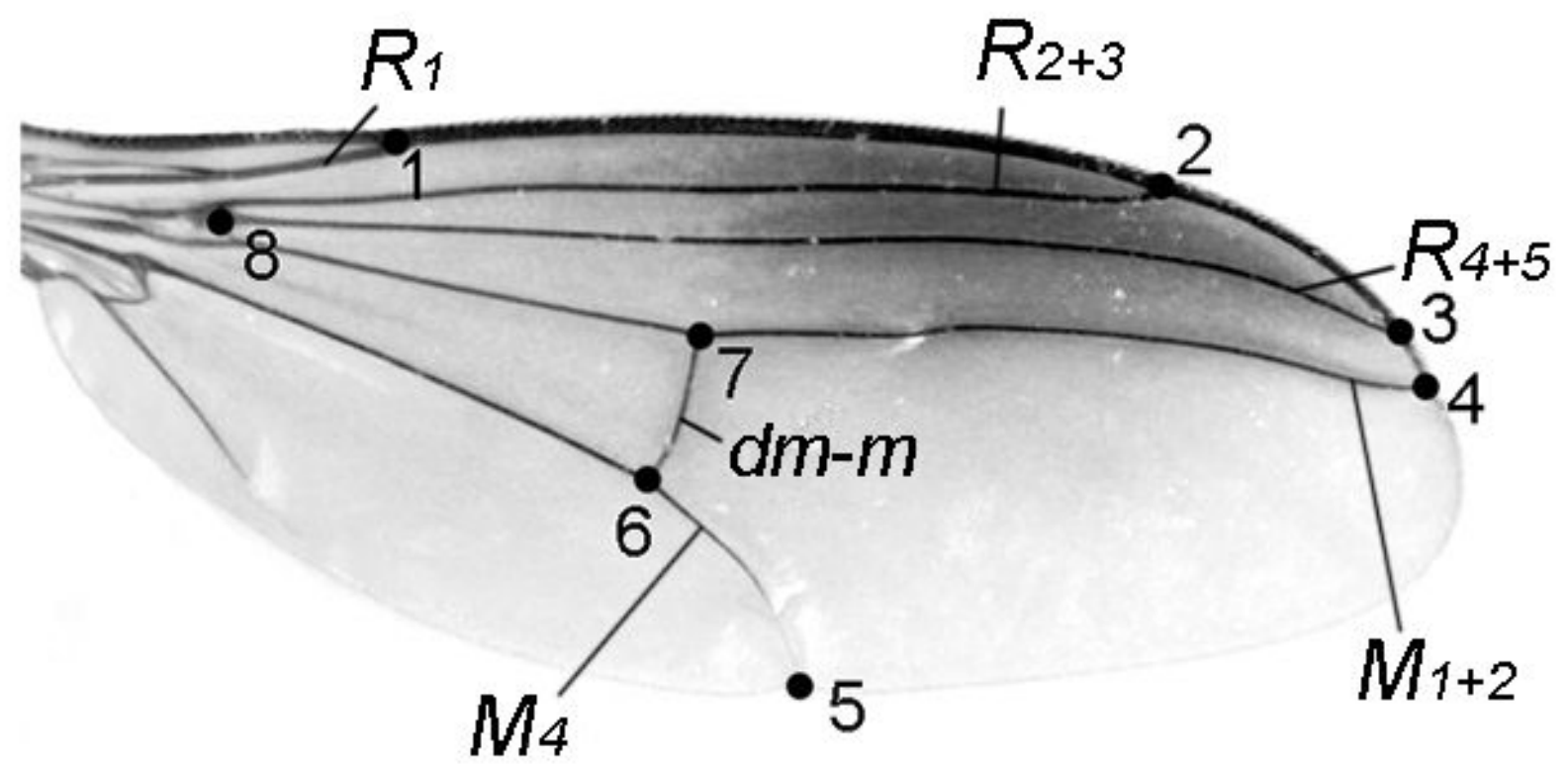

Fig. 1. Wing of Poecilobothrus regalis (male) and landmarks position

From LM coordinates wing centroid size and Procrustes residuals (shape data) were obtained. Wing centroid sizes (CS) were calculated as the square root of the square distance between each LM and the wing centroid. Procrustes residuals were obtained by Generalized Procrustes Analysis: wings were scaled to a unit centroid size, superimposed on the origin so that their mean coordinates become 0,0 , then specimens were rotates so that the distance between all the LMs of all the wings become minimal [31]. Data analyses and graphical output were performed using the methods of multivariate statistics in MorpholJ software [32] and Statistica 10 [33].

The analysis of variance (ANOVA) with a Tukey post-hoc test was used to estimate the effect of generation, sex and side on the wing size. The degrees of asymmetry were calculated as the difference between the centroid size of the left and the right wings $(L-R)$. The skew and kurtosis of the distribution of $(\mathrm{L}-\mathrm{R})$ values were calculated in order to check antisymmetry; and the Kolmogorov -
Smirnov test was used to check the normality of distribution.

We used a regression of FA degree on centroid size to characterize the relationship between developmental processes and the wing size. Inspection of the reliability of distinction between FA in the generations was carried out by the t-test. To assess the equality of FA variance for sexes and generations, they were tested by Levene's test. Relationship between amount of FA and size was examined by computing correlation between average (within individual) centroid wing size and the degree of FA, measured as the quotient from dividing the difference between left and right centroid sizes of the square of sum of the left and right centroid sizes.

$$
\text { Degree of } \mathrm{FA}=\frac{L-R}{(L+R)^{2}}
$$

Procrustes ANOVA was performed to assess contribution of inter-generation, intra-generation and sex-related variation, directional asymmetry 
(DA) and fluctuating asymmetry (FA, measured as the effect of side and specimen interaction) to the total shape variation. We used canonical variate analysis (CVA) to determine the most important features for discriminating the groups. To visualize shape variation thin-plate spline transformations of LM position were used. We computed Procrustes distance between the mean shape of males and females and among generations to quantify the amount of differences [34] and tested them using the permutation procedure with 10,000 iterations. The effect of FA was evaluated by the sidespecimen interaction of Procrustes distance.

An allometric effect was evaluated by a multivariate regression of Procrustes residuals on centroid size. The basic idea is that variation of the dependent variables can be divided into two parts (predicted and residual components). The predicted values can be calculated from the slope of this regression line and are the estimates of allometric relationships.

In order to compare the shape variations, attributed to different sources (intergeneration variation, sexual dimorphism, asymmetry) we used a Mantel test of matrix correlations $\left(\mathrm{R}_{\mathrm{M}}\right)$. This test simulated the null hypothesis that two matrices are dissimilar [35].

\section{Results}

The analysis of variance (ANOVA) showed that both generation $(\mathrm{F}=513.4$, Tukey post hoc $\mathrm{P}<0.001)$ and sex $(\mathrm{F}=12.9$, Tukey post hoc $\mathrm{P}<0.001)$ have significant effects on the wing size. An exception of this was the comparison between 2017 and 2018 generations, where no evidence was found for a significant difference in the wing size (Tukey post hoc $\mathrm{P}=0.987$ ). Males' wings were, on average, $3 \%$ larger than those of females. The flies, both males and females, of 2015 year had smaller wings than others. Moreover, when males and females of each generation were analyzed separately the significant differences in size between left and right wings were only found in females of 2015 and 2018 and males of 2017.

The Procrustes ANOVA results also revealed highly significant differences in wing shape between sexes $(\mathrm{F}=366.2, \mathrm{P}<0.0001)$ and among generations $(\mathrm{F}=3.9, \mathrm{P}<0.0001)$. The effect of measurement error as not statistically significant for both wing size $(\mathrm{F}=0.28, \mathrm{P}=1.0)$ and shape $(\mathrm{F}=0.07, \mathrm{P}=1.0)$. The effect of side on shape had low statistical significance (female 2015: $\mathrm{F}=1.12$, $\mathrm{P}=0.03$; female 2018: $\mathrm{F}=0.80, \mathrm{P}=0.66$; male 2017: $F=1.69, P=0.06)$. The effect of $F A$ on size and shape was significant both for males $(\mathrm{F}=$
646.58, $\mathrm{P}<0.0001 ; \mathrm{F}=11.10, \mathrm{P}<0.0001)$ and females $(\mathrm{F}=825.30, \mathrm{P}<0.0001 ; \mathrm{F}=20.91, \mathrm{P}<$ $0.0001)$.

\section{Directional asymmetry}

Results of t-test indicated significant differences in wing size between left and right sides in males of $2017(\mathrm{t}=2.18, \mathrm{P}=0.034)$, females of $2015(\mathrm{t}=2.03, \mathrm{P}=0.046)$ and $2018(\mathrm{t}=2.34$, $\mathrm{P}=0.023)$. Left minus right centroid size values distribution for all groups were nearly normal. Left wings were, on average, $1.61 \%$ larger than right ones. Investigation of the distribution of female $(\mathrm{L}-\mathrm{R})$ values showed that there were not significant skewed $\left(\mathrm{A}_{\mathrm{s}} \pm \mathrm{SE}=-0.36 \pm 0.22 ; \mathrm{P}>0.20\right)$ and leptokurtic $(\mathrm{K} \pm \mathrm{SE}=0.27 \pm 0.49 ; \mathrm{P}>0.20)$. However, male $(\mathrm{L}-\mathrm{R})$ values were right skewed $\left(\mathrm{A}_{\mathrm{s}} \pm \mathrm{SE}=1.33 \pm 0.17 ; \mathrm{P}<0.001\right)$ and strongly leptokurtic $(\mathrm{K} \pm \mathrm{SE}=6.44 \pm 0.34 ; \mathrm{P}<0.001)$. The absence of platykurtic in both males and females suggested no evidence of antisymmetry.

The CVA resulted that shape variations were associated with the displacement of LM 5, i.e. left wings were wider than right (Fig. 2). LM5 has more posterior position on the left than on the right wing, LMs 6 and 7 are more proximal, LM are more posterior. The coefficients of correlation between all three covariance matrices were high and confirmed the similarity between three cases of DA (males of 2017 and females of 2015: $\mathrm{R}_{\mathrm{M}}=0.88, \mathrm{P}<0.0001$; males of 2017 and females of 2018: $R_{M}=0.81, P<0.0001$; females of 2015 and 2018: $\left.\mathrm{R}_{\mathrm{M}}=0.88, \mathrm{P}<0.0001\right)$.

The matrix correlations between covariance matrices of DA and intra-generation variability also showed some similarities (males of 2017: $\mathrm{R}_{\mathrm{M}}=$ $0.67, \mathrm{P}=0.004$; females of 2015: $\mathrm{R}_{\mathrm{M}}=0.87, \mathrm{P}<$ 0.0001; males of 2018: $\mathrm{R}_{\mathrm{M}}=0.77, \mathrm{P}=0.0001$ ). The results of regression analysis revealed the relatively high influence of centroid size to wing shape. Allometry explained from $20.17 \%$ of total variations associated with DA in female of 2018 to $26.19 \%$ in male of 2017.

\section{Differences between generations}

Wing shape variations among generations were considered using CVA separately for males and females. Females differed more clearly than males. Most of the variance $(71.12 \%)$ of females fell in the first canonical variate (CV1), which was associated with displacements of LM 5 and 6, i.e. with changes in the placements of the posterior crossvein and the apical section of $M_{4}$. CV1 described a variation between females of the generation of 2015 and 2017 (Fig. 3). 


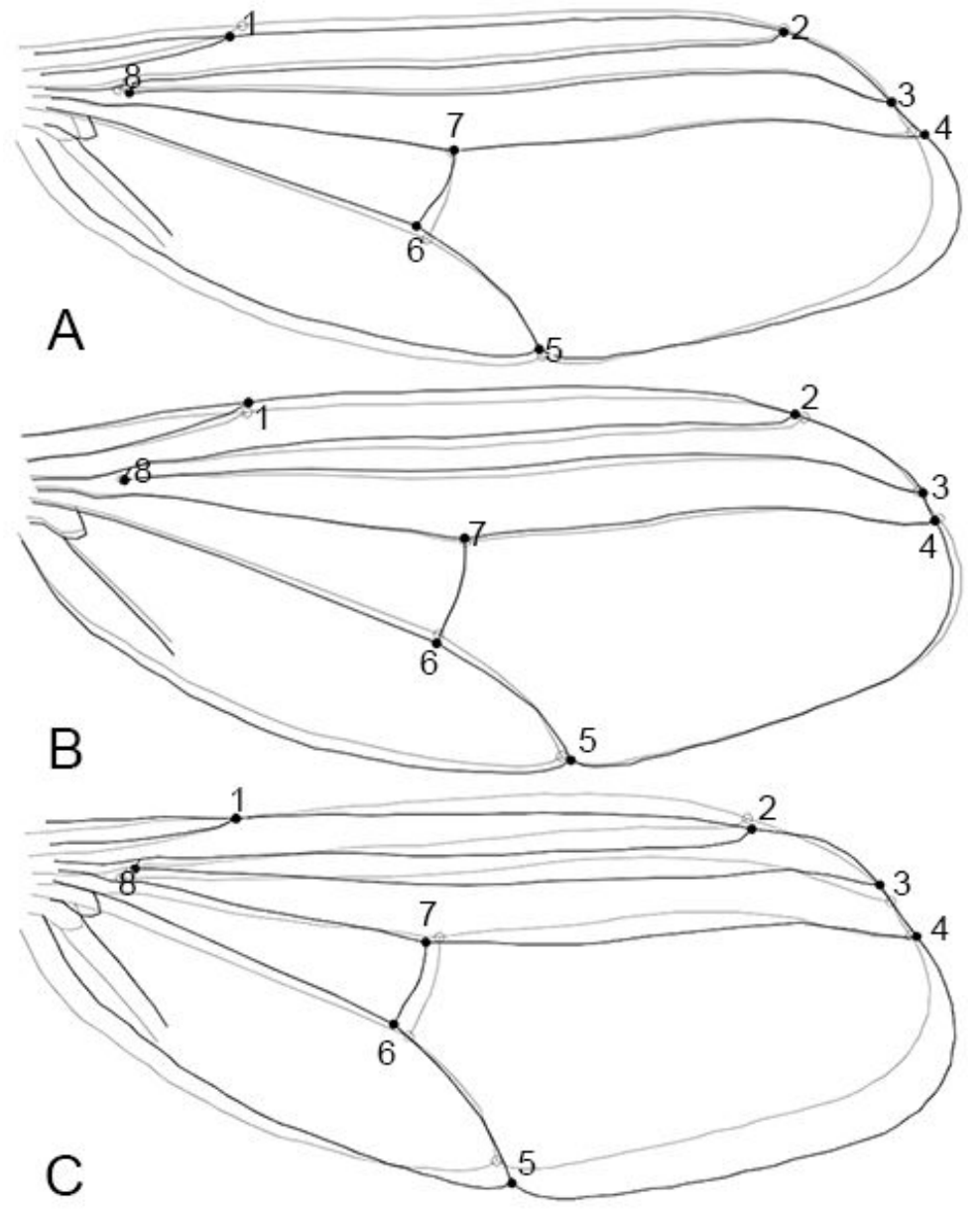

Fig. 2. Shape changes associated with DA of Poecilobothrus regalis, showed as the differences between left (black line) and right (grey line) wings: A - females of 2015; B - females of 2018; C - males of 2017

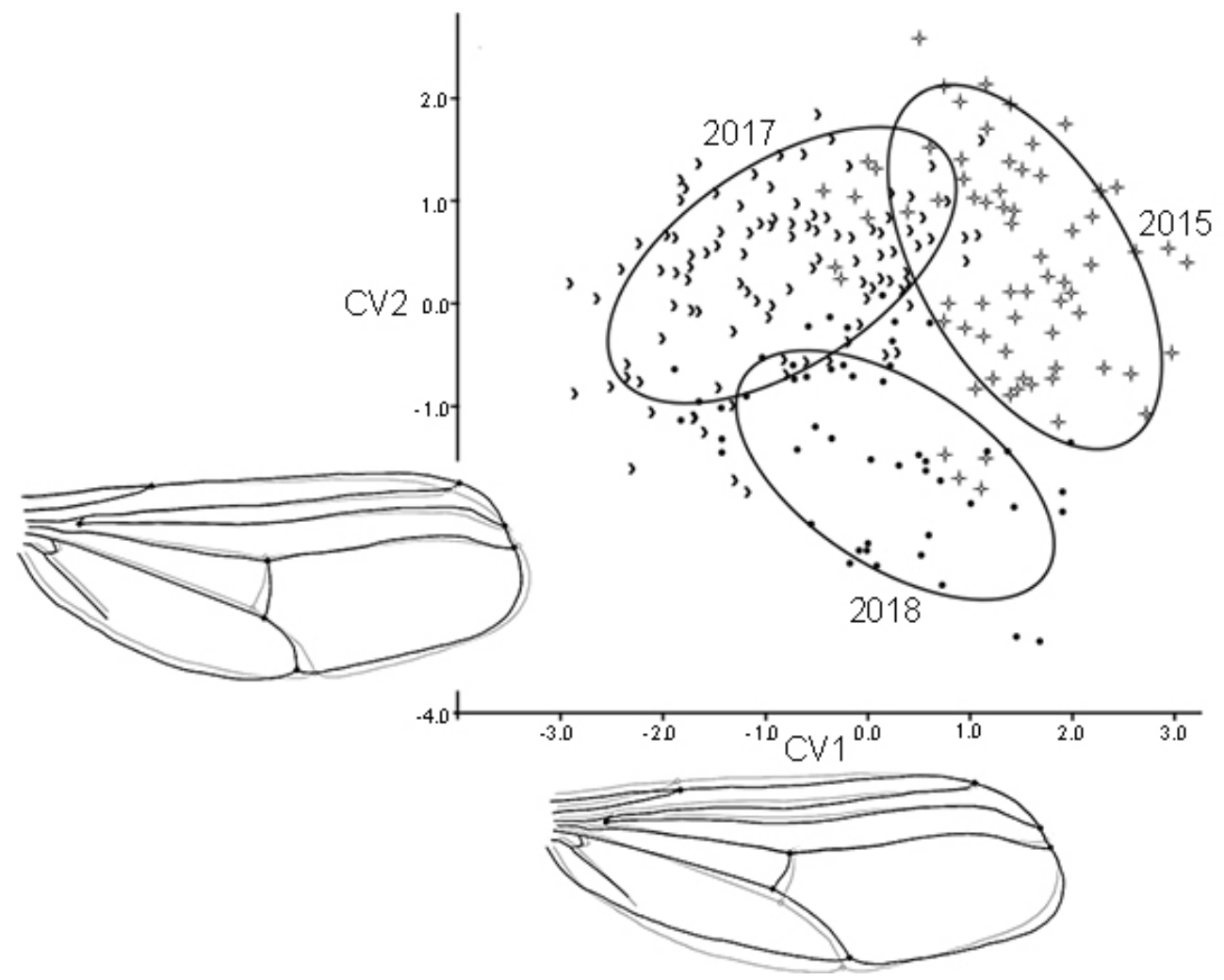

Fig. 3. Scatter plot of CVA showing shape differentiation between three generations of Poecilobothrus regalis females. Associated shape changes are shown 
The largest share of variation associated with the second canonical variate $(28.88 \%$ of total variance explained) is located at the LM 2, 5 and 6 defining apex shape and length of the apical section of $M_{4}$. Into the morphospace the second canonical variate separated the exemplars belonging to the generations of 2018 and 2015-2017. The scatter plot from CV1 and CV2 showed little overlap among generations. Procrustes distance ranged from 0.0077 (between females of 2015 and 2018) to 0.0109 (between females of 2015 and 2017). All differences were statistically significant $(\mathrm{P}<0.0001)$.
CVA of male wings produced two highly significant axes. CV1 with more that $91 \%$ of variation separated exemplars of generations of 2015 and 2017-2018. The major deformations between generations of 2015 and 2017-2018 were associated with position of LM 1, 2 and 5, so the anterior wing margin and the apical section of $M_{4}$ were particularly subject to change. CV2 with $8.84 \%$ separated exemplars of generations of 2017 and 20152017 and associated with displacements of LM 5 and 7 (Fig. 4). Procrustes distance ranged from 0.0044 (between males of 2017 and 2018) to 0.0090 (between males of 2015 and 2017). All differences were statistically significant $(\mathrm{P}<0.0001)$.

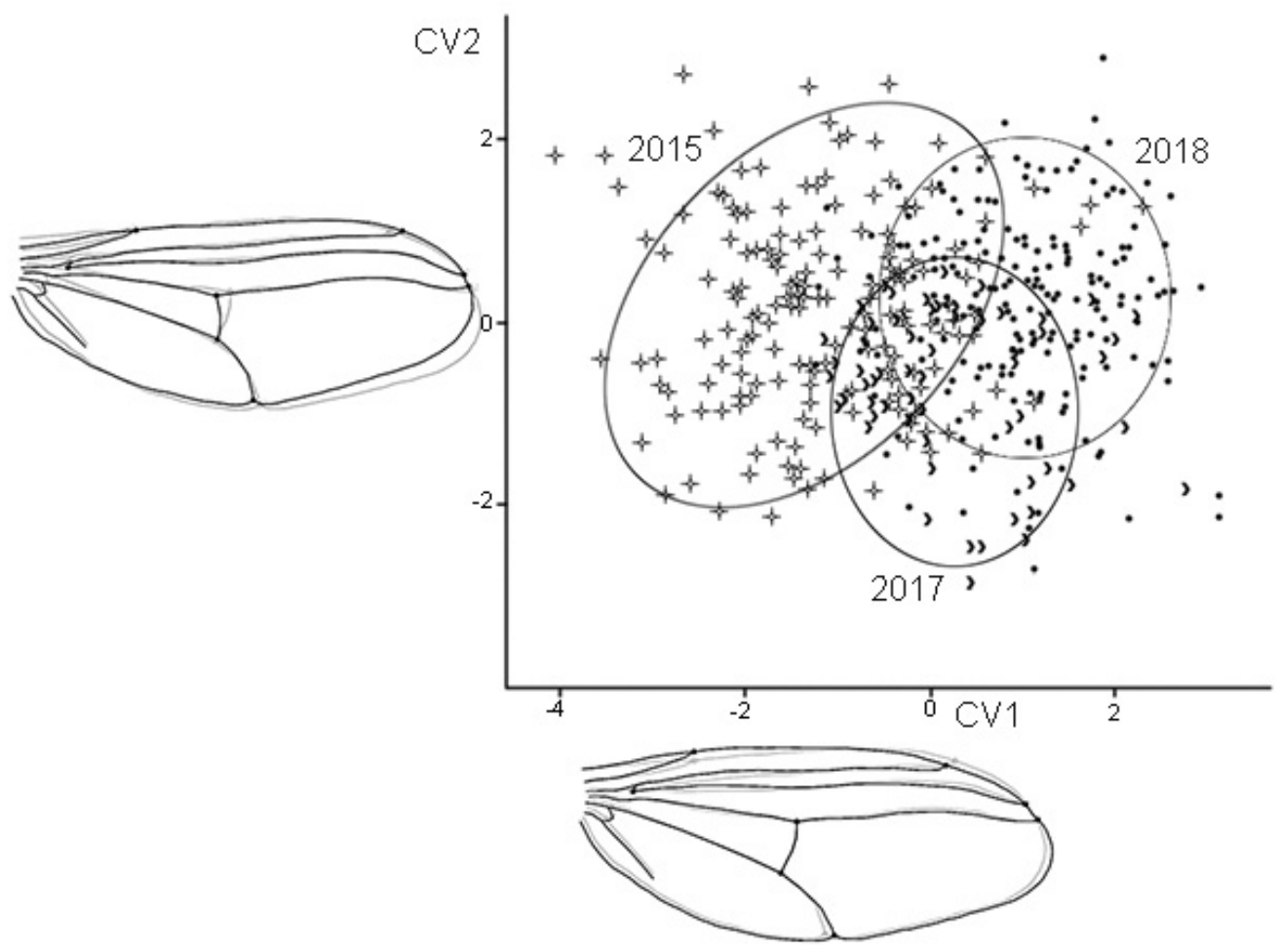

Fig. 4. Scatter plot of CVA showing shape differentiation between four generations of Poecilobothrus regalis males. Associated shape changes are shown

To characterize the developmental basis of intergenerational variation, we compared the covariance matrices of between-generation and intragenerational effects. The matrix correlation showed their significant similarity $\left(\mathrm{R}_{\mathrm{M}}=0.92, \mathrm{P}<\right.$ $0.001)$. For both patterns of variation the largest differences were found at the posterior cross-vein (LM 7), at the apex of $M_{4}$ (LM 5) and at the anterior wing margin (LM 2). Moreover, when analyzing the correlation between intergenerational variation of males and females, it is also possible to note their significant similarity $\left(\mathrm{R}_{\mathrm{M}}=0.88, \mathrm{P}<0.001\right)$.

Allometric components of intergenerational variation were $27.96 \%$ in males and $24.07 \%$ in females. Allometric part of wing variation is char- acterized by the fact that when wings become larger, the apex of wing becomes more pointed and the apex of $M_{4}$ displaces distally.

\section{Sexual dimorphism}

Males are about $3.5 \%$ larger than females for wing centroid size. In all cases the differences are statistically significant. In this context particular interest was the increase of sexual size dimorphism from the generation of 2015 (males are about 1.31 $\%$ larger than females) to the generation of 2018 (males are about $5.12 \%$ larger than females).

The data obtained support the previous studies of sexual dimorphism which established that the 
shape changes between male and female are primarily associated with displacements of LM 2, 5 and 7 ; in particular, males possessed far more proximal insertion points of the $R_{1}$ and $M_{4}[26,28]$. Our results of CVA suggested that a greatest feature of sexual dimorphism is a displacement of the apices of $M_{4}$ (LM 5) and $R_{2+3}(\mathrm{LM} 2)$.

Procrustes distance between males and females ranged from 0.0550 (generation of 2015) to 0.0557 (generation of 2017). Sex-related differences were statistically significant in all three cases $(\mathrm{P}<0.0001)$. The patterns of sexual shape dimorphism in all generations were significantly similar $\left(\mathrm{R}_{\mathrm{M}}=0.95, \mathrm{P}<0.001\right)$.

\section{Fluctuating asymmetry}

Leven's test of variances showed that the males and females' FA variances and generations' variances are equal $(\mathrm{P}=0.0005)$. Moreover, comparison of the amount of FA (Procrustes distances for each individual) revealed no significant difference both between sexes and among generations $(\mathrm{P}<0.0001)$. Correlation between average centroid wing size and the degree of FA for males and females were 0.03 and 0.09 , respectively. For the generations, correlations were $0.18,-0.21$, and 0.13 for males of 2015, 2017 and 2018, and 0.36, -0.11 and 0.00 for females 2015, 2017 and 2018, respectively. Only the females' 2015 correlation was significant $(\mathrm{P}<0.05)$.

The matrix correlation among covariance matrices for the fluctuating asymmetry and individual variation were high $\left(\mathrm{R}_{\mathrm{M}}=0.94, \mathrm{P}<0.0001\right.$ in males, $\mathrm{R}_{\mathrm{M}}=0.93, \mathrm{P}<0.0001$ in females).

\section{Discussion}

Our studies lead to the following conclusion concerning the wing shape variation of Poecilobothrus regalis. First, the differences in the wing size between generations were statistically more significant that differences in the wing shape. It is not surprising because the wing size in Diptera appears to be strongly differentiated and influenced by environmental conditions during ontogeny, for instance, samples of Drosophila melanogaster reared at higher temperatures had smaller wings [36].

The recent studies revealed limited utility of the wing size in discriminating between populations and morphologically similar species [1,2] and also indicated a great influence of environmental condition on the wing size [37]. Size differences often were not related to a geographic cline [38, 39]. This result suggests that the wing size is a character that required cautious consideration when inter- preting taxonomical studies and separating species, because they may be relatively uninformative.

Shape analysis revealed subtle, but statistical significant variation between generations. Allometry has been suggested to be an important component of intergeneration shape variation. The increases of the wing size were accompanied by an expansion in the distal part of wings and the apical part of $M_{4}$, whereas non-allometric components of intergeneration shape variation varied from generation to generation.

Furthermore, as witnessed by high positively matrix correlations there was marked similarity in shape variability among sexes. This fact can be explained in two ways: on the one hand, it is possible that a certain environmental factor directly affects equally on the wing shape of both female and male flies; on the other hand, the experiments [40] indicated that selection operated on traits of one sex caused a correlated response of the homologous traits in the other sex. If we take into account the irregular DA, the second hypothesis seems more likely. In case if some environmental factor affected males and females simultaneously, a simultaneous DA would be expected

Secondly, in three out of seven cases, significant DA was found, left wings were larger that right and differently shaped in males of the generation 2017 and in females of the generations of 2015 and 2018. DA was not apparent in every generation, and even if DA was present, it was apparent only for the one sex. This indicates that DA cannot be recognized as a characteristic of the species or even the population.

Several studies $[27,41,42]$ reported data on the presence of statistical significant DA in the wing size and shape for different dipteral species, including Musca domestica, Drosophila melanogaster and Glossina palpalis gambiensis. Pelabon and Hansen [42] have concluded that DA is a sufficiently frequent phenomenon in insects, and the cases when left wing was greater that the right wing are more common than the opposite. In addition, in was clearly proved that DA does not have any adaptive value when the coefficient of variation of left minus right centroid size values more than $100 \%$.

Consistent DA was described for Nearctic dolichopodid species - Erebomyia exalloptera Runyon \& Hurley, 2004, males of which had the left wing $6 \%$ greater in area than right. The shape differences attributed to DA occurs in the posterior wing compartment, between apical parts of $M_{1+2}$ and $M_{4}$ [43]. According to the authors observation this degree of DA did not affect male aerobatic ability.

We observed DA in both males and females, but only males DA was right skewed and strongly 
leptokurtic. It suggests that there might be a larger selection pressure on males than females, that has resulted in survival of the most resistant males. Additionally, it is to be noted that the wing shape changes attributed to DA in Poecilobothrus regalis are very similar to those presented in Erebomyia exalloptera and the species examined by Klingenberg and McIntyre [41]. Shape changes were always associated with displacement of the point of intersection of the costal vein with the vein reaching the distal part of the wing (LM 2 in P. regalis), insertion of $M_{4}$ and the wing margin (LM 5) and posterior cross-vein.

Apparently, many authors suggested that it is more likely that DA is a deviation from symmetry resulting from increasing environmental stress, the most extreme show of fluctuating asymmetry. Although there was no evidence for the fact that selection results in changes in the level of DA $[44,45]$, it cannot be denied that such type of asymmetry might have a genetic basis: supposedly, flies are predicted to show the certain kind of DA when the development stability has been weakened due to the applied stress. Evolution conservation of ability to DA in different not closely related taxa suggests that DA is an ancient phenomenon.

Thirdly, we did not detect any significant difference of the pattern of sexual shape dimorphism of the three generation studied, and individual variation among generation had a minor effect on changing the range of sexual dimorphism. It seems to be assumed, therefore, that sexual dimorphism of the wing shape is a population characteristic. Sexual shape dimorphism may be described as a taxonomic character at a specific level after careful considerations of other populations.

Speaking of FA, it is important to note, that Klingenberg and McIntyre [42] inferred that FA and individual variation showed similar patterns of covariation among landmarks. Our results obtained confirm this conclusion. There was no evidence that the intra-generation variation and fluctuating asymmetry are controlled by different developmental processes.

The amount of FA did not differ among groups. The absence of distinctions indicated that ecological stress could be similar in all years or the amount of FA is more heavily influenced by evolutionary history of the population, than by environmental variables. Based on the data for DA, the second point of view is more likely, but it seems appropriate to study different populations with the aim to provide the evidence for this hypothesis.

Mǿller [46] showed that long-tailed Hirundo rustica males are more symmetrical than shorttailed and have the most mating success. This fact may suggest that an FA is an indicator of fitness. Assuming that larger males should adapt more, it was predicted to show lower degree of FA. However, our results did not confirm this view.

We are grateful to Dr. Oleg Negrobov (Voronezh, Voronezh State Universiry) for provision of advice and assistance in identification of material.

\section{References}

1. Schutze, M. K. Wing shape as a potential discriminator of morphologically similar pest taxa within the Bactocera dorsalis species complex (Diptera: Tephritidae) / M. K. Schutze, A. Jessup, A. R. Clarke // Bulletin of Entomological Research. - 2012. - Vol. 102. - P. 103-111.

2. An integrated approach to delimiting species borders in the genus Chrysotoxum Meigen, 1803 (Diptera: Syrphidae), with description of two new species / Z. Nedeljković, J. Ačanski, D. Mihajla, D. Obreht-Vidaković, A. Ricarte, A. Vujić // Contribution to Zoology. - 2015. - Vol. 84 (4). - P. 285-304.

3. Wing morphometrics as a tool in species identification of forensically important blow flies of Thailand / N. Sontigun, K. L. Sukontason, B. K. Zajac, R. Zehner, K. Sukontason, A. Wannasan, J. Amendt // Parasites \& Vectors. 2017. - Vol. 10. - P. 229-242.

4. Pepinelli, M. Geometric morphometrics as a tool for interpreting evolutionary transitions in the black fly wing (Diptera: Simuliidae) / M. Pepinelli, M. Spironello, D. C. Currie // Zoological Journal of the Linnean Society. 2003. - Vol. 169. - P. 377-388.

5. Klingenberg, C. P. Testing and quantifying phylogenetic signals and homoplasy in morphometric data / C. P. Klingenberg, N. A. Gidaszewski // Systematic Boilogy. - 2010. - Vol. 59 (3). - P. 245-261.

6. Morpho morphometrics: shared ancestry and selection drive the evolution of wing size and shape in Morpho butterflies / N. Chazot, S. Panara, N. Zilbermann, P. Blandin, Y. L. Poul, R. Cornette, M. Elias, V. Debat // Evolution. 2015. - Vol. 70 (1). - P. 181-194.

7. Bitner-Mathé, B. C. Heritability, phenotypic and genetic correlations of size and shape of Drosophila mediopunctata wings / B. C. Bitner-Mathé, L. B. Klaczko // Heredity. - 1999. - Vol. 83. - P. 688-696.

8. Birdsall, K. Genetic variation for the position of wing veins in Drosophila melanogaster / K. Birdsall, E. Zimmerman, K. Teeter, G. Gibson // Evolution \& Development. - 2000. - Vol. 2 (1). - P. 16-24.

9. Imasheva, A. G. Variation in wing length in Eurasian natural populations of Drosophila melanogaster / A. G. Imasheva, O. A. Bubli, O. E. Lazebny // Heredity. - 1996. - Vol. 72. - P. 508-514. 
10. Clarke, G. M. Fluctuating asymmetry of invertebrate populations as a biological indicator of environmental quality / G. M. Clarke // Environmental pollution. - 1993. - Vol. 82. - P. 207-211.

11. Palmer, A. R. Fluctuating asymmetry: measurement, analysis, patterns / A. R. Palmer, C. Strobeck // Annual Review of Ecology, Evolution and Systematics. - 1986. - Vol. 17. - P. 391-421.

12. Thornhill, R. Developmental stability, disease and medicine / R. Thornhill, A. P. Mǿller // Biological Review of the Cambridge Philosophical Society. - 1997. - Vol. 72 (4). - P. 497-548.

13. Size, symmetry, and sexual selection in the housefly, Musca domestica / D. Goulson, L. Bristow, E. Elderfield, K. Brinklow, B. Parry-Jones, J. W. Chapman // Evolution. - 1999. - Vol. 53 (2). - P. 527-534.

14. Floate, K. D. Flies under stress: a test of fluctuating asymmetry as a biomonitor of environmental quality / K. D. Floate, A. S. Fox // Ecological Applications. - 2009. - Vol. 10 (5). - P. 1541-1550.

15. Hosken, D. J. Developmental stability in yellow ding flies (Scathophaga stercoraria): fluctuating asymmetry, heterozygosity and environmental stress / D. J. Hosken, W. U. Blanckenhorn, P. I. Ward // Journal of Evolutionary Biology. - 2000. - Vol. 13. - P. 919-926.

16. Hutn, M. K. Fluctuating asymmetry and sexual selection in Medeterranean fruitfly (Diptera, Tephritidae) / M. K. Hutn, C. S. Crean, R. J. Wood, A. S. Gilburn // Biological Journal of the Linnean Society. - 1998. Vol. 64. - P. 385-396.

17. Markov, T. A. Male size, developmental stability, and mating success in natural populations of three Drosophila species / T. A. Markov, J. P. Ricker // Heridity. - 1992. - Vol. 96. - P. 122-127.

18. Whitlock, M. The heritability of fluctuating asymmetry and the genetic control of developmental stability / M. Whitlock // Biological sciences. - 1996. - Vol. 263 (1372). - P. 849-853.

19. Breuker, C. J. Lack of response to selection for lower fluctualing asymmetry of mutant eyespots in the butterfly Bicyclus anynana / C. J. Breuker, P. M. Brakefield // Heredity. - 2003. - Vol. 91. - P. 17-27.

20. Fluctuating asymmetry as a measure of ecological stress in Drosophila melanogaster (Diptera: Drosophilidae) / V. Trotta, F. C. F. Clboli, F. Garoia, D. Grifoni, S. Cavicchi // European Journal of Entomology. - 2005. Vol. 102. - P. 196-205.

21. Zhang, L. L. A study on the phylogeny of Dolichopodinae from the Palaearctic and Oriental realms, with description of three new genera (Diptera, Dolichopodidae) / L. L. Zhang, D. Yang // Acta Zootaxonomica Sinica. - 2005. Vol. 30 (1). - P. 180-190.

22. Bernasconi, M. V. Phylogeny of European Dolichopus and Gymnopternus (Diptera: Dolichopodidae) and the significance of morphological characters inferred from molecular data / M. V. Bernasconi, M. Pollet, M. VariniOoijen, P. I. Ward // Europe Journal of Entomology. - 2007. - Vol. 104. - P. 601-607.

23. Chursina, M. A. Phylogenetic signal of wing shape in the Dolichopodinae subfamily (Diptera, Dolichopodidae) / M. A. Chursina, O. P. Negrobov // Entomological Review. - 2018. - Vol. 98 (5). - P. 688-700.

24. Smith, K. G. V. Note on the courtship and predaceous behavior of Poecilobothrus nobilitatus L. (Dipt. Dolichopodidae) / K. G. V. Smith, D. W. Empson // British journal of animal behavior. - 1955. - Vol. 3 (1). - P. $32-34$.

25. Land, M. F. The visual control of courtship behavior in the fly Poecilobothrus nobilitatus / M. F. Land // Journal of comparative Physiology. - 1993. - Vol. 173. - P. 595-603.

26. Chursina, M. A. Intraspecific variation and asymmetry in wing shape of dolichopodid flies (Diptera, Dolichopodidae) / M. A. Chursina // International Journal of Entomology Research. - 2017. - Vol. 2 (5). - P. 10-20.

27. Phenotypic variation of the housefly, Musca domestica: amount and pattern of wing shape asymmetry in wild population and laboratory colonies / J. Ludoški, M. Djurakic, B. Pastor, A. I. Martínez-Sánchez, S. Roji, V. Milankov // Bulletin of Entomological Research. - 2014. - Vol. 104. - P. 35-47.

28. Chursina, M. A. Intraspecific variation in wing shape of Poecilobothrus regalis (Meigen, 1824) (Diptera, Dolichopodidae) / M. A. Chursina, O. P. Negrobov // Journal of Insect Biodiversity. - 2016. - Vol. 4 (16). - P. 1-11.

29. Rohlf, F. J. Tps-Dig version 2.32 / F. J. Rohlf. - 2003. - URL: https://tpsdig2.software.informer.com/

30. Bookstein, F. L. Morphometric tools for landmark data, geometry and biology / F. L. Bookstein. - Cambridge : Cambridge University Press, 1991. - 456 p.

31. Rohlf, F. J. Extension of the Procrustes method for the optimal superimposed of landmarks / F. J. Rohlf, D. E. Slice // Systematic Zoology. - 1990. - Vol. 39. - P. 40-59.

32. Klingenberg, C. P. MorphoJ: an integrated software package for geometric morphometrics / C. P. Klingenberg // Molecular Ecology Resources. - 2011. - Vol. 11. - P. 353-357.

33. StatSoft Inc. STATISTICA - data analysis software system. Ver. 12. - 2012. - URL: http://www.statsoft.com

34. Zelditch, M. L. Geometric Morphometrics for Biologists: A Primer / M. L. Zelditch, D. L. Swiderski. - London : Elsevier Academic Press, 2004. - 416 p.

35. Klingenberg, C. P. Left-right asymmetry of fly wings and the evolution of body axes / C. P. Klingenberg, G. S. McIntyre, S. D. Zaklan // Proceedings of the Royal Society. - 1998. - Vol. 265. - P. 1255-1259.

36. Cavicchi, S. Temperature-related divergence in experimental population of Drosophila melanogaster. I. Genetic and developmental basis of wing size and shape variation / S. Cavicchi, D. Guerra, G. Giorgy, C. Pezzoli // Genetics. - 1985. - Vol. 109. - P. 665-689.

37. Loh, R. Variability of wing size and shape in three populations of a recent Brazilian invader, Zaprionus indianus (Diptera: Drosophilidae), from different habitats / R. Loh, B. C. Bitner-Mathé // Genetica. - 2005. - Vol. 125 (2-3). P. 271-281. 
38. Brown, K. R. Comparative wing morphometrics of some calyptrate Diptera / K. R. Brown // Australian Journal of Entomology. - 1979. - Vol. 18. - P. 289-303.

39. Wing geometry as a tool for studying the Lutzomyia longipalpis (Diptera: Psychodidae) complex / J. De la Riva, F. Le Pont, A. Matias, S. Mollinedo, J. P. Dujardin // The Memorial do Instituto Oswaldo Cruz. - 2001. Vol. 96 (8). - P. 1089-1094.

40. Lande, R. Sexual dimorphism, sexual selection, and adaptation in polygenic character / R. Lande // Evolution. 1980. - Vol. 34 (2). - P. 292-305.

41. Klingenberg, C. P. Geometric morphometrics of developmental instability: analyzing patterns of fluctuating asymmetry with Procrustes methods / C. P. Klingenberg, G. S. McIntyre // Evolution. - 1998. - Vol. 52 (5). P. 1363-1375.

42. Pelabon, C. On the adaptive accuracy of directional asymmetry in insect wing size / C. Pelabon, T. F. Hansen // Evolution. - 2008. - Vol. 62 (11). - P. 2855-2867.

43. Runyon, J. B. A new genus of long-legged f lies displaying remarkable wing directional asymmetry / J. B. Runyon, R. L. Hurley // Proceedings of the Royal Society of London. B. (Suppl.). - 2015. - Vol. 271. - P. 114-116.

44. Leamy, L. J. A search for quantitative trait loci affecting asymmetry of mandibular characters in mice / L. J. Leamy, E. J. Routman, J. M. Cheverud // Evolution. - 1997. - Vol. 51(3). - P. 957-969.

45. Leamy, L. J. Quantitative trait loci for fluctuating asymmetry of discrete skeletal characters in mice / L. J. Leamy, E. J. Routman, J. M. Cheverud // Heredity. - 1998. - Vol. 8. - P. 509-518.

46. Mǿller, A. P. Fluctuating asymmetry in male sexual ornaments may reliably reveal male quality / A. P. Mǿller // Animal Behaviour. - 1990. - Vol. 40 (6). - P. 1185-1187.

\section{References}

1. Schutze M. K., Jessup A., Clarke A. R. Bulletin of Entomological Research. 2012, vol. 102, pp. $103-111$.

2. Nedeljković Z., Ačanski J., Mihajla D., Obreht-Vidaković D., Ricarte A., Vujić A. Contribution to Zoology. 2015, vol. 84 (4), pp. 285-304.

3. Sontigun N., Sukontason K. L., Zajac B. K., Zehner R., Sukontason K., Wannasan A., Amendt J. Parasites \& Vectors. 2017, vol. 10, pp. 229-242.

4. Pepinelli M., Spironello M., Currie D. C. Zoological Journal of the Linnean Society. 2003, vol. 169, pp. 377-388.

5. Klingenberg C. P., Gidaszewski N. A. Systematic Boilogy. 2010, vol. 59 (3), pp. 245-261.

6. Chazot N., Panara S., Zilbermann N., Blandin P., Poul Y. L., Cornette R., Elias M., Debat V. Evolution. 2015 , vol. 70 (1), pp. 181-194.

7. Bitner-Mathé B. C., Klaczko L. B. Heredity. 1999, vol. 83, pp. 688-696.

8. Birdsall K., Zimmerman E., Teeter K., Gibson G. Evolution \& Development. 2000, vol. 2 (1), pp. 16-24.

9. Imasheva A. G., Bubli O. A., Lazebny O. E. Heredity. 1996, vol. 72, pp. 508-514.

10. Clarke G. M. Environmental pollution. 1993, vol. 82, pp. 207-211.

11. Palmer A. R., Strobeck C. Annual Review of Ecology, Evolution and Systematics. 1986, vol. 17, pp. 391-421.

12. Thornhill R., Mǿller A. P. Biological Review of the Cambridge Philosophical Society. 1997, vol. 72 (4), pp. $497-548$.

13. Goulson D., Bristow L., Elderfield E., Brinklow K., Parry-Jones B., Chapman J. W. Evolution. 1999, vol. 53 (2), pp. 527-534.

14. Floate K. D., Fox A. S. Ecological Applications. 2009, vol. 10 (5), pp. 1541-1550.

15. Hosken D. J., Blanckenhorn W. U., Ward P. I. Journal of Evolutionary Biology. 2000, vol. 13, pp. 919-926.

16. Hutn M. K., Crean C. S., Wood R. J., Gilburn A. S. Biological Journal of the Linnean Society. 1998, vol. 64, pp. 385-396.

17. Markov T. A., Ricker J. P. Heridity. 1992, vol. 96, pp. 122-127.

18. Whitlock M. Biological sciences. 1996, vol. 263 (1372), pp. 849-853.

19. Breuker C. J., Brakefield P. M. Heredity. 2003, vol. 91, pp. 17-27.

20. Trotta V., Clboli F. C. F., Garoia F., Grifoni D., Cavicchi S. European Journal of Entomology. 2005, vol. 102, pp. 196-205.

21. Zhang L. L., Yang D. Acta Zootaxonomica Sinica. 2005, vol. 30 (1), pp. 180-190.

22. Bernasconi M. V., Pollet M., Varini-Ooijen M., Ward P. I. Europe Journal of Entomology. 2007, vol. 104, pp. 601-607.

23. Chursina M. A., Negrobov O. P. Entomological Review. 2018, vol. 98 (5), pp. 688-700.

24. Smith K. G. V., Empson D. W. British journal of animal behavior. 1955, vol. 3 (1), pp. 32-34.

25. Land M. F. Journal of comparative Physiology. 1993, vol. 173, pp. 595-603.

26. Chursina M. A. International Journal of Entomology Research. 2017, vol. 2 (5), pp. 10-20.

27. Ludoški J., Djurakic M., Pastor B., Martínez-Sánchez A. I., Roji S., Milankov V. Bulletin of Entomological Research. 2014, vol. 104, pp. 35-47.

28. Chursina M. A., Negrobov O. P. Journal of Insect Biodiversity. 2016, vol. 4 (16), pp. 1-11.

29. Rohlf F. J. Tps-Dig version 2.32. 2003. Available at: https://tpsdig2.software.informer.com/

30. Bookstein F. L. Morphometric tools for landmark data, geometry and biology. Cambridge: Cambridge University Press, 1991, $456 \mathrm{p}$. 
31. Rohlf F. J., Slice D. E. Systematic Zoology. 1990, vol. 39, pp. 40-59.

32. Klingenberg C. P. Molecular Ecology Resources. 2011, vol. 11, pp. 353-357.

33. StatSoft Inc. STATISTICA - data analysis software system. Ver. 12. 2012. Available at: http://www.statsoft.com

34. Zelditch M. L., Swiderski D. L. Geometric Morphometrics for Biologists: A Primer. London: Elsevier Academic Press, 2004, 416 p.

35. Klingenberg C. P., McIntyre G. S., Zaklan S. D. Proceedings of the Royal Society. 1998, vol. 265, pp. 1255-1259.

36. Cavicchi S., Guerra D., Giorgy G., Pezzoli C. Genetics. 1985, vol. 109, pp. 665-689.

37. Loh R., Bitner-Mathé B. C. Genetica. 2005, vol. 125 (2-3), pp. 271-281.

38. Brown K. R. Australian Journal of Entomology. 1979, vol. 18, pp. 289-303.

39. De la Riva J., Le Pont F., Matias A., Mollinedo S., Dujardin J. P. The Memorial do Instituto Oswaldo Cruz. 2001, vol. 96 (8), pp. 1089-1094.

40. Lande R. Evolution. 1980, vol. 34 (2), pp. 292-305.

41. Klingenberg C. P., McIntyre G. S. Evolution. 1998, vol. 52 (5), pp. 1363-1375.

42. Pelabon C., Hansen T. F. Evolution. 2008, vol. 62 (11), pp. 2855-2867.

43. Runyon J. B., Hurley R. L. Proceedings of the Royal Society of London. B. (Suppl.). 2015, vol. 271, pp. 114-116.

44. Leamy L. J., Routman E. J., Cheverud J. M. Evolution. 1997, vol. 51(3), pp. 957-969.

45. Leamy L. J., Routman E. J., Cheverud J. M. Heredity. 1998, vol. 8, pp. 509-518.

46. Mǿller A. P. Animal Behaviour. 1990, vol. 40 (6), pp. 1185-1187. 